\title{
PREVALENCE OF RISK FACTORS FOR HEPATITIS C AND ASSOCIATED FACTORS: a population-based study in southern Brazil
}

\author{
David Timm KVITKO', Gisele Alsina Nader BASTOS² and Maria Eugênia Bresolin PINTO³
}

\begin{abstract}
Context - The hepatitis $\mathrm{C}$ is a severe public health problem worldwide because its consequences. Studies which aim at determining the prevalence of risk factors are really important to understand the problem. Objective - To estimate the prevalence and factors associated with some risk factors for the disease in a community, called Restinga, located in the city of Porto Alegre, RS, Brazil. Method - This paper is based on a population-based cross-sectional study, with systematic sampling and proportional to the size of census tracts in which 3,391 adults answered a standardized questionnaire. Results - The prevalence of blood transfusion among the people who were interviewed was $14.98 \%, 60.83 \%$ of those had it before 1993 . A total of $16.16 \%$ of the people had a tattoo, $7.23 \%$ wore a piercing, $1.09 \%$ said they had already injected illicit drugs and $12.39 \%$ reported previous hospitalization. Prevalence ratios showed that tattoos were more common among young people, piercings among women and illicit drugs among men. Conclusions - To summarize, the recognition of risk factors for hepatitis $\mathrm{C}$ enables proper screening of possible carriers of the hepatitis $\mathrm{C}$ virus, thus enabling a reduction in virus shedding. However, being only possible if health services are prepared to deal with hepatitis $\mathrm{C}$ virus, through education and public awareness.
\end{abstract}

HEADINGS - Hepatitis C. Risk factors. Population groups. Brazil, southern.

\section{INTRODUCTION}

Hepatitis $\mathrm{C}$ is a severe public health problem nowadays because its consequences. Present estimations show that $1 \%$ to $2 \%$ of the world population is infected with hepatitis $\mathrm{C}$ virus (HCV) and the absolute number of infected people is close to 170 million $^{(1,29,32)}$. The prevalence of the disease varies all over the world. It can be considered low in the United Kingdom and the Scandinavian Peninsula (0.01\%-0.1\%), in the Americas, Western Europe, Australia and South Africa $(0.2 \%-0.5 \%)$. It is intermediate in Brazil, Eastern Europe and some regions in Africa and Asia. The highest rates are found in Egypt (17\%-26\%), Mongolia and Pakistan $^{(32)}$. In Brazil, a study conducted in 1999 by the Brazilian Hepatology Society showed the highest rates in the North Region of the country $(2.12 \%)$, intermediate rates in the Center-West $(1.04 \%)$, Northeast $(1.19 \%)$ and Southeast $(1.43 \%)$ and low rates in the South $(0.65 \%)$, with a prevalence of $0.6 \%$ in the state of Rio Grande do $\mathrm{Sul}^{(27)}$.

The disease may become chronic in up to $80 \%$ of the cases, despite the lack of symptoms in the majority of the infections. It may evolve to hepatic cirrhosis $(5 \%-20 \%)^{(23)}$, hepatocellular carcinoma $(1 \%-5 \%)^{(8)}$ or hepatic failure $(4 \%)^{(3)}$. The average period for such complications is between 20 and 30 years from the first contact with the virus. The number of population based studies about hepatitis $\mathrm{C}$ is still limited and those available either have non-representative sample groups or have specific subject groups, such as blood donors ${ }^{(1,10,29,32)}$. In countries with continental dimensions, like Brazil, performing these studies may be a very hard task once one can find enormous demographical, social and cultural inequities among people ${ }^{(10)}$.

Specific group studies (blood donors, illicit drug users) show association between HCV infection and risk factors such as blood transfusion ${ }^{(11,26)}$, previous surgery $^{(11)}$, organ transplantation ${ }^{(12,20)}$, hemodialy$\operatorname{sis}^{(12,20)}$, frequent hospitalizations ${ }^{(11,12)}$, occupational exposition $^{(11,20)}$, intravenous (IV) drugs ${ }^{(11,20)}$, previous infection with the hepatitis B virus (HBV) ${ }^{(11)}$, tattoos $^{(19,20)}$ or piercings ${ }^{(19,20)}$, being a barber shop client ${ }^{(19,20)}$, being circumcised ${ }^{(20)}$ and acupuncture ${ }^{(18)}$. Sexual transmission is still controversial. Some studies show high infection rates in people with multiple sexual partners ${ }^{(25)}$ and others point to weak evidences relating $\mathrm{HCV}$ infection and sexual contact ${ }^{(26)}$.

Illicit drug users are considered the highest risk

\footnotetext{
Declared conflict of interest of all authors: none

1 Universidade Federal de Ciências da Saúde de Porto Alegre; ${ }^{2}$ Escola de Gestão em Saúde, Hospital Moinhos de Vento; ${ }^{3}$ Departamento de Saúde Coletiva, Universidade Federal de Ciências da Saúde de Porto Alegre, RS, Brasil

Correspondence: Dr. David Timm Kvitko - Avenida Protásio Alves, 749, ap. 22 - 90410-000 - Porto Alegre, RS, Brazil. E-mail: davidkvitko@gmail.com
} 
group to $\mathrm{HCV}$ transmission, bearing in mind that as time goes by, there is a cumulative effect in the probability of one of these subjects to get in contact with the virus according to the period and the frequency of drug abuse ${ }^{(24)}$. It is believed that the use of non-injected drugs is also a risk factor for $\mathrm{HCV}$, due to the fact that drug users share accessories in the inhalation and preparation processes $^{(7)}$. The available studies also pointed out a higher prevalence rate of $\mathrm{HCV}$ in patients who had a tattoo ( $8 \%-25 \%)$ and wore a piercing $(14 \%-51 \%)^{(17,23)}$. It is said that the use of these esthetic accessories is often related to a more "underground" social behavior, which includes alcoholism, drug addiction and acts of felony ${ }^{(5,17)}$.

The inexistence of a vaccine for $\mathrm{HCV}$ and the limited treatment of chronic cases make hepatitis $\mathrm{C}$ an important public health problem. This situation is aggravated by the lack of knowledge about the total number of infected individuals and the prevalence of risk factors in Brazil. Acknowledging the risk factors is important to call health care providers' attention to people who may need special attention so that they can help reduce the disease dissemination ${ }^{(30)}$.

Therefore, the present study aims at estimating the prevalence and the associated factors with the following risk factors for hepatitis C: blood transfusion prior to 1993, piercings, tattoos and injected illicit drugs in a sample from the city of Porto Alegre, RS, Brazil.

\section{METHOD}

The data which was used in this paper is part of an epidemiology survey conducted by a hospital association called Associação Hospitalar Moinhos de Vento (AHMV) in a partnership with the Health Ministry. Its main objective was identifying the socioeconomic and demographic features in a community called Restinga and the southern part of the city of Porto Alegre as well as assessing the way people use the public health services available in this community. A secondary objective, among others, was to known the risk factors for infection with hepatitis C. Therefore the sample was calculated to achieve this goal.

The target subjects were adults over 20 years old and the data collection took place in the period from June to December, 2009. The survey was conducted by previously trained interviewers who lived in the community. If the subject chosen to be part of the sample was not home at the time of the scheduled interview, the interviewer tried to reach the subject at least 2 more times. If the subject was not found after these attempts, the field work supervisor scheduled an interview by phone. The process was the same for the people who refused to take part in the study, so that after all these attempts, the refusal could be acknowledged.

The sample size was calculated with StatCalc module of EpiInfo Software. It was calculated based on the least common risk factor for hepatitis C (drug addiction - $0.9 \%$ among the inhabitants). Considering a margin of error of 3 percentage points for a $95 \%$ confidence interval, the software indicated that at least 2,096 participants were required to meet the study criteria.
The sampling process which was used was systematic with probability proportional to size. Due to the possibility of data obsolescence in the 2000 demographic census ${ }^{(16)}$, the first step taken was identifying the number of existing households in the neighborhood. When the number of households which were inhabited $(29,929)$ was divided by the number of desired households $(1,750)$, the result was 17 . This result was the interval between households which were included in the sample.

Information about the following risk factors for hepatitis C was collected: blood transfusion previous to 1993 , tattoos, piercings, current and past IV drug addiction, and hospitalization in the previous year. The analyzed expositions were gender, age, self-referred skin color (Caucasian and non-Caucasian), socioeconomic condition (according to the criteria called "Critério de Classificação Econômica do Brasil" - CCEB - recommended by the Associação Brasileira de Empresas de Pesquisas - ABEP) (2), schooling, marital status, self-perception of health status (very good, good, regular, bad, very bad) and alcohol consumption (Score AUDIT) ${ }^{(4)}$.

Ten percent of the interviewees were interviewed by phone so that data could be collected reliably.

The data was typed into Office Remark and edited, tabulated and analyzed in the program Stata 9.0 (Stata Corporation, College Station, United States). The data was described using average and standard deviation to the variables of normal and median distribution and quartile for the non-Gaussian ones. Percentage comparisons were made with Chi Square test, all of them with a significance level of 0.05 . The data was presented with both a prevalence ratio and a confidence interval of $95 \%$.

Our project follows the 196/96 regulation of the Health National Committee and it was assessed by the Ethical and Human's Research Committee of AHMV (2009/28 protocol) and of Universidade Federal de Ciências da Saúde de Porto Alegre (UFCSPA) (11/740 protocol) before the data gathering has started. All subjects signed two copies of a Free and Clarified Consent Term and were provided with a copy signed by the responsible researcher. Both information privacy and the right to quit the study at any moment were assured to every participant without any kind of onus.

\section{RESULTS}

There was 3,699 eligible adults found in the 1,750 chosen households, among these 3,391 accepted to take part in the survey, which represented a $91.7 \%$ response rate. The sample consisted of $44.12 \%$ males and $77.74 \%$ Caucasian. The socioeconomical level $\mathrm{C}$ was the most frequent one $(56.04 \%)$. Forty point sixteen percent of the people had studied for a period ranging from 5 to 8 years. More than half of the interviewees were married $(66.12 \%)$. The majority of the people declared that their self-perception of health status was very good/good $(64.84 \%)$ and most of them were categorized in the Zone 1 of the AUDIT score (Table 1).

Among the risk factors for hepatitis C, $14.98 \%$ of the individuals got at least one blood transfusion, $60.83 \%$ of those had it before 1993. From the interviewees $16.16 \%$ had 
TABLE 1. Demographic and socioeconomic characteristics and risk factors for infection with hepatitis C. Porto Alegre, RS, 2009 ( $n=3391$ )

\begin{tabular}{|c|c|}
\hline Variables & $\begin{array}{c}\text { Sample } \\
\text { description } \mathrm{n}(\%)\end{array}$ \\
\hline \multicolumn{2}{|l|}{ Gender } \\
\hline Masculine & $1496(44.12)$ \\
\hline Feminine & $1895(55.88)$ \\
\hline \multicolumn{2}{|l|}{ Age } \\
\hline $20-29$ & $792(23.36)$ \\
\hline $30-39$ & $648(19.11)$ \\
\hline $40-49$ & $718(21.17)$ \\
\hline $50-59$ & $595(17.55)$ \\
\hline 60 or more & $638(18.81)$ \\
\hline \multicolumn{2}{|c|}{ Self-referred skin color } \\
\hline White & $2636(77.74)$ \\
\hline Not white & $755(22.26)$ \\
\hline \multicolumn{2}{|c|}{ Socioeconomic condition } \\
\hline A-B & $1139(33.99)$ \\
\hline $\mathrm{C}$ & $1878(56.04)$ \\
\hline D-E & $334(9.97)$ \\
\hline \multicolumn{2}{|l|}{ Schooling } \\
\hline $0-4$ & $565(17.74)$ \\
\hline $5-8$ & $1279(40,16)$ \\
\hline $9-11$ & $1053(33.06)$ \\
\hline 12 or more & $288(9.04)$ \\
\hline \multicolumn{2}{|l|}{ Marital status } \\
\hline Married & $2108(62.16)$ \\
\hline Single & $744(21.94)$ \\
\hline Separate & $280(8.26)$ \\
\hline Widower & $259(7.64)$ \\
\hline \multicolumn{2}{|c|}{ Self-perception of health status } \\
\hline Very good/good & $2196(64.84)$ \\
\hline Regular & $1006(29.70)$ \\
\hline Bad/very bad & $185(5.46)$ \\
\hline \multicolumn{2}{|l|}{ Audit } \\
\hline Zone 1 & $3071(90.56)$ \\
\hline Zone 2 & $263(7,76)$ \\
\hline Zone 3 & $23(0.68)$ \\
\hline Zone 4 & $34(1.00)$ \\
\hline \multicolumn{2}{|c|}{ Ever performed blood transfusion } \\
\hline Yes & $508(14.98)$ \\
\hline No & $2883(85.01)$ \\
\hline \multicolumn{2}{|c|}{ Blood transfusion previous to $1993(\mathrm{n}=508)$} \\
\hline No & $199(39.17)$ \\
\hline Yes & $309(60.83)$ \\
\hline \multicolumn{2}{|l|}{ Tattoo } \\
\hline No & $2843(83.84)$ \\
\hline Yes & $548(16.16)$ \\
\hline \multicolumn{2}{|l|}{ Piercing } \\
\hline No & $3146(92.77)$ \\
\hline Yes & $245(7.23)$ \\
\hline \multicolumn{2}{|l|}{ Drug addiction } \\
\hline No & $3354(98.91)$ \\
\hline Yes & $37(1.09)$ \\
\hline \multicolumn{2}{|c|}{ Hospitalization previous to 1993} \\
\hline No & $2971(87.61)$ \\
\hline Yes & $420(12.39)$ \\
\hline
\end{tabular}

at least one tattoo and $7.23 \%$ wore piercings. A small number $(1.09 \%)$ said that they had already used IV drugs and $12.39 \%$ were hospitalized in the previous year.

In the crude analysis of the possible associated factors and the five risk factors for the infection with hepatitis $\mathrm{C}$, it was observed that blood transfusion and piercings were more frequent among women. The female population also declared a higher rate of hospitalization in the year preceding the survey. Illicit drugs were more common among males $(P<0.001)$ (Table 2).

In terms of age, there was a direct association between increased age and increased likelihood of blood transfusion and recent hospitalization, and inverse relationship between age and tattoos, piercings and drugs.

In the analysis of socioeconomic variables, a statistically significant difference between social class and piercings was observed; prevalence among adults in social class D/E was lower than in social class A/B. In the same way, it was observed that the higher the educational level, the higher the prevalence of tattoos and piercings $(P<0.001)$.

Tattoos and piercings were less frequent among respondents who declared that their self-perception of health status was poor or very poor. This group, however, showed a higher frequency of recent hospitalization. Heavy alcohol consumption was directly associated with the risk factor for drug use $(P<0.001)$.

\section{CONCLUSIONS}

The lack of population-based studies that estimate the prevalence of risk factors for hepatitis $\mathrm{C}$ brought up some issues to the analysis of the data collected in this study. The majority of studies found regarding this disease is aimed at determining the prevalence of the virus especially in specific populations. Therefore, we highlight, among the advantages of this study, its population-based delineation on a representative sample of a region with approximately 100,000 inhabitants. It is worth mentioning that the low percentage of refusals and losses of $8.3 \%$ strengthens the internal validity of the study.

Among the limitations of the study, we point out that the extrapolation of the results to other populations should be done with caution, bearing in mind that although it is a population-based study, the sample analyzed is part of a very specific population of Porto Alegre who live in a situation of social vulnerability. This study aimed at determining the prevalence of risk factors for infection with the HCV, not directly the prevalence of hepatitis $\mathrm{C}$. Therefore, no blood was collected nor were the interviewees asked if they had hepatitis $\mathrm{C}$, what can also be considered a limitation.

Most of the 508 patients who got a blood transfusion sometime in their lives had it before 1993. The risk of contamination by $\mathrm{HCV}$ is approximately 10 times greater in individuals who received transfusions before the implementation of screening in blood banks than in those who did not get any transfusions ${ }^{(6)}$. Furthermore, higher age groups were those who were exposed more times to this procedure. The results 
TABLE 2. Crude analysis of the different risk factors related to infection with hepatitis $C$ virus and associated factors, represented in prevalence ratio. Porto Alegre, RS, 2009 ( $\mathrm{n}=3391$ )

\begin{tabular}{|c|c|c|c|c|c|c|c|c|c|c|}
\hline \multirow[t]{2}{*}{ Variable } & \multicolumn{2}{|c|}{$\begin{array}{c}\text { Transfusion } \\
\text { previous to } 1993\end{array}$} & \multicolumn{2}{|l|}{ Tattoo } & \multicolumn{2}{|l|}{ Piercing } & \multicolumn{2}{|c|}{ Drug addiction } & \multicolumn{2}{|c|}{ Hospitalization } \\
\hline & RP & $P$ & RP & $P$ & RP & $P$ & RP & $P$ & RP & $P$ \\
\hline Gender & & 0.036 & & 0.761 & & $<0.001$ & & 0.005 & & $<0.001$ \\
\hline Masculine & 1,00 & & 1,00 & & 1,00 & & 1,00 & & 1,00 & \\
\hline Feminine & $1,19(1,01-1,40)$ & & $0,98(0,84-1,14)$ & & $2,79(2,08-3,75)$ & & $0,38(0,19-0,75)$ & & $1,42(1,18-1,71)$ & \\
\hline Age & & $<0.001$ & & $<0.001$ & & $<0.001$ & & $<0.001$ & & 0.005 \\
\hline $20-29$ & 1,00 & & 1,00 & & 1,00 & & 1,00 & & 1,00 & \\
\hline $30-39$ & $1,31(0,75-2,28)$ & & $0,68(0,57-0,80)$ & & $0,38(0,28-0,50)$ & & $1,13(0,52-2,46)$ & & $1,04(0,78-1,39)$ & \\
\hline $40-49$ & $1,95(1,17-3,24)$ & & $0,30(0,23-0,37)$ & & $0,07(0,04-0,12)$ & & $0,68(0,28-1,63)$ & & $0,86(0,63-1,15)$ & \\
\hline $50-59$ & $2,15(1,30-3,54)$ & & $0,09(0,06-0,15)$ & & - & & $0,31(0,09-1,07)$ & & $1,24(0,94-1,64)$ & \\
\hline 60 or more & $2,05(1,25-3,38)$ & & $0,05(0,03-0,09)$ & & $0,01(0,00-0,05)$ & & $0,10(0,01-0,73)$ & & $1,44(1,10-1,87)$ & \\
\hline Skin color & & 0.291 & & 0.371 & & 0.930 & & 0.485 & & 0.089 \\
\hline White & 1,00 & & 1,00 & & 1,00 & & 1,00 & & 1,00 & \\
\hline Not white & $0,91(0,77-1,08)$ & & $0,92(0,76-1,11)$ & & $0,99(0,74-1,32)$ & & $1,29(0,63-2,66)$ & & $1,19(0,97-1,46)$ & \\
\hline $\begin{array}{l}\text { Socioeconomic } \\
\text { condition }\end{array}$ & & 0.233 & & 0.246 & & 0.005 & & 0.143 & & 0.435 \\
\hline A-B & 1,00 & & 1,00 & & 1,00 & & 1,00 & & 1,00 & \\
\hline $\mathrm{C}$ & $0,98(0,84-1,13)$ & & $0,93(0,79-1,10)$ & & $0,88(0,68-1,14)$ & & $2,93(1,22-7,04)$ & & $0,90(0,74-1,10)$ & \\
\hline D-E & $0,85(0,66-1,09)$ & & $0,86(0,65-1,15)$ & & $0,41(0,22-0,75)$ & & $0,57(0,07-4,71)$ & & $1,29(0,97-1,72)$ & \\
\hline Schooling & & 0.247 & & $<0.001$ & & $<0.001$ & & 0.092 & & 0.009 \\
\hline $0-4$ & 1,00 & & 1,00 & & 1,00 & & 1,00 & & 1,00 & \\
\hline $5-8$ & $0,89(0,75-1,06)$ & & $2,24(1,61-3,13)$ & & $2,18(1,29-3,70)$ & & $0,94(0,41-2,16)$ & & $0,82(0,64-1,04)$ & \\
\hline $9-11$ & $0,88(0,72-1,06)$ & & $3,59(2,59-4,97)$ & & $3,86(2,31-6,44)$ & & $0,67(0,27-1,69)$ & & $0,66(0,51-0,87)$ & \\
\hline 12 or more & $0,91(0,67-1,22)$ & & $2,84(1,93-4,19)$ & & $4,17(2,34-7,42)$ & & $0,25(0,03-1,95)$ & & $0,74(0,50-1,08)$ & \\
\hline Marital status & & 0.534 & & $<0.001$ & & 0.646 & & 0.050 & & $<0.001$ \\
\hline Married & 1,00 & & 1,00 & & 1,00 & & 1,00 & & 1,00 & \\
\hline Single & $0,85(0,67-1,08)$ & & $1,73(1,48-2,02)$ & & $3,14(2,46-4,00)$ & & $4,14(2,06-8,34)$ & & $1,09(0,87-1,37)$ & \\
\hline Separate & $1,10(0,92-1,33)$ & & $0,66(0,46-0,95)$ & & $0,68(0,36-1,28)$ & & $1,74(0,50-6,06)$ & & $0,98(0,69-1,39)$ & \\
\hline Widower & $0,88(0,70-1,11)$ & & $0,08(0,02-0,24)$ & & $0,07(0,01-0,52)$ & & $1,25(0,28-5,52)$ & & $1,98(1,53-2,55)$ & \\
\hline $\begin{array}{l}\text { Self-perception of } \\
\text { health status }\end{array}$ & & 0.293 & & $<0.001$ & & $<0.001$ & & 0.594 & & $<0.001$ \\
\hline Very good/good & 1,00 & & 1,00 & & 1,00 & & 1,00 & & 1,00 & \\
\hline Regular & $1,16(1,00-1,35)$ & & $0,57(0,47-0,69)$ & & $0,45(0,32-0,62)$ & & $1,04(0,51-2,13)$ & & $1,76(1,45-2,13)$ & \\
\hline Bad/ very bad & $1,03(0,82-1,31)$ & & $0,28(0,15-0,51)$ & & $0,18(0,06-0,55)$ & & $1,55(0,47-5,11)$ & & $3,37(2,61-4,34)$ & \\
\hline$\overline{\text { AUDIT }}$ & & 0.350 & & $<0.001$ & & 0.006 & & $<0.001$ & & 0.410 \\
\hline Zone 1 & 1,00 & & 1,00 & & 1,00 & & 1,00 & & 1,00 & \\
\hline Zone 2 & $1,13(0,85-1,49)$ & & $2,08(1,71-2,54)$ & & $1,81(1,27-2,56)$ & & $4,57(2,14-9,77)$ & & $0,89(0,62-1,27)$ & \\
\hline Zone 3 & $1,66(1,54-1,79)$ & & $2,06(1,10-3,84)$ & & $3,23(1,47-7,08)$ & & $5,81(0,82-41,2)$ & & $0,35(0,05-2,39)$ & \\
\hline Zone 4 & $0,83(0,31-2,22)$ & & $1,19(0,57-2,48)$ & & $0,44(0,06-3,02)$ & & $15,7(5,74-43,0)$ & & $2,13(1,21-3,77)$ & \\
\hline
\end{tabular}

found in our study are alarming, for up to 1993 screening tests for $\mathrm{HCV}$ were not compulsory for blood and blood derivatives in blood banks ${ }^{(31)}$. It is known that the prevalence of $\mathrm{HCV}$ increases with age and number of blood transfusions as patients are more likely to have had contact with the viral particle ${ }^{(9,28)}$. Also, being older facilitates disease cornification because of the longer period of exposition, elevating the risk for cirrhosis and hepatocellular carcinoma ${ }^{(8)}$.

Even though higher age seems to increase the chances of a patient suffering from hepatitis $\mathrm{C}^{(9,28)}$, this aspect cannot be taken into account when the risk factor in analysis is having a tattoo as this type of exposition is typical in younger populations on the grounds that the data analysis revealed a progressive dropping in the prevalence ratio as the subjects got older. Laumann and Derick ${ }^{(17)}$ found similar results in their study. According to them, youths are more likely to have multiple tattoos and $65 \%$ of all the women who had tattoos had them made before the age of 24. This study also showed a high prevalence of tattoos among single people
$(25 \%)$ and among people who lived with a partner but were not married (41\%). Similar data was found in our study in which the prevalence rate among unmarried people was higher than among other marital statuses. Thus, the presence of tattoos can be associated to a lifestyle with more risky activities, such as drug and alcohol abuse $\mathrm{e}^{(5,17)}$. To summarize, these subjects would have an increased risk of contact with $\mathrm{HCV}$ and, consequently, they are more likely to get infected.

It is known that wearing a piercing is considered a risk factor for hepatitis $\mathrm{C}^{(19,20)}$. Our results showed that piercings are more common among women than among men, confirming what was found in our references ${ }^{(23)}$. Earlobes were the most frequently pierced body part among women, given the socio-cultural implications related to this type of adornment. In order to have a body part safely pierced and avoid exposure to $\mathrm{HCV}$, people should look for services which respect biosafety rules during the procedure.

In our study, socioeconomic classes $\mathrm{D}$ and $\mathrm{E}$ were the ones with the lowest rates of body piercing. This fact might 
be interpreted as the lower the rate of body piercing, the lower the prevalence of the disease, meaning that less effort could be made to prevent hepatitis in these groups. However, studies show that the lowest social classes have a higher risk of infection with $\mathrm{HCV}^{(26)}$. Bearing this in mind, we understand that the contamination with $\mathrm{HCV}$ occurs mostly via other ways, that is, there are other risk factors which are more important in these populations.

The prevalence of drug abuse was lower in the female group, which was expected, because men usually have a lifestyle characterized by higher risk behavior, which includes drug abuse, multiple sex partners and unprotected sex ${ }^{(9)}$ and it is more common for men to experience some type of illicit drug during life when compared to women ${ }^{(17)}$. Bearing this in mind, the risk of contamination can be considered higher among males.

The progressive increase in the prevalence ratio of AUDIT score among IV drug users proves that individuals generally do not make use of only one type of drug. This was corroborated in two studies that showed that alcohol consumption was higher among illicit drug users ${ }^{(18)}$ and methamphetamine users $^{(15)}$ when compared to non-users. Murphy et al. ${ }^{(22)}$ showed that seropositive individuals consume more alcohol than non-infected people. These results are alarming for people who consume more than $50 \mathrm{~g}$ of alcohol a day have a threefold risk of developing more severe hepatic lesions that can lead to cirrhosis ${ }^{(13)}$ and therefore, aggravate their clinical condition.

Brandão and Fuchs ${ }^{(6)}$ showed a trend of association between HCV and hospital admission for clinical, surgical and parenteral treatments. However, there is a paucity of data about contamination by medical procedures and nosocomial exposure ${ }^{(14)}$, complicating its use as relevant variables in the increasing prevalence of hepatitis C. Our prevalence of hospitalization was slightly higher than $10 \%$, but we did not find any association with the independent variables, even though individuals are more likely to be exposed to infections in hospitals.

The profile of the individuals who are at risk of getting infected by HCV in specific populations, such as blood donors, drugs users, hemodialysis patients, and inmates, is well documented in the literature ${ }^{(8,29,32)}$. It is believed that new studies like this must be conducted to identify the prevalence of risk factors for hepatitis $\mathrm{C}$ in the general population as they are rare in the literature and are important to plan public health programs.

Hepatitis $\mathrm{C}$ is a severe public health problem nowadays. New and correct programs of screening and patient orientation are necessary to reduce the disease dissemination. These kinds of programs are only possible if the public health systems are aware of the risks and are ready to deal with $\mathrm{HCV}$, warning and educating target populations. Thus, recognizing the magnitude of the risk factors for this disease in a community allows the correct screening of potential carriers of $\mathrm{HCV}$.

\section{ACKNOWLEDGEMENTS}

The authors are grateful to the Associação Hospitalar Moinhos de Vento and the Ministério da Saúde for giving us access to the database which was used in the study and for the financial support.

Collaborators - D. T. Kvitko was responsible for the statistical analysis, writing the article and proofreading.

G. A. N. Bastos was responsible for conceptualizing the study, data collection and she also helped proofread the article.

M. E. B. Pinto was responsible for supervising and proofreading the article

Sources of Funding - This research was conducted under the "Projeto Desenvolvimento de Técnicas de Operação e Gestão de Serviços de Saúde em uma Região Intramunicipal de Porto Alegre - Distritos da Restinga e Extremo-Sul", funding with the "Programa de Apoio ao Desenvolvimento Institucional do Sistema Único de Saúde (PROADI-SUS)" signed between the Ministério da Saúde and Associação Hospitalar Moinhos de Vento through the adjustment term number 06/2008, signed on November 17th, 2008.

\section{CEPs Approvals}

UFCSPA CEP - 075/05 - 26/04/2011

AHMV CEP - 2009/28 - 22/04/2009

Kvitko DT, Bastos GAN, Pinto MEB. Prevalência de fatores de risco para hepatite C e fatores associados: estudo de base populacional no sul do Brasil. Arq Gastroenterol. 2013;50(2):117-22.

RESUMO - Contexto - A hepatite C é um grave problema de saúde pública mundial, devido as suas consequências. Trabalhos voltados à determinação da prevalência dos fatores de risco são essenciais para a compreensão do problema. Objetivo - Estimar a prevalência e os fatores associados a alguns fatores de risco da enfermidade na comunidade da Restinga, localizada na cidade de Porto Alegre, Rio Grande do Sul, Brasil. Método - Realizou-se estudo transversal de base populacional, com amostragem sistemática e proporcional ao tamanho dos setores censitários, no qual 3391 adultos responderam a um questionário padronizado. Resultados - A prevalência de transfusão de sangue foi 14,98\% sendo que desses, $60,83 \%$ realizaram antes de 1993, 16,16\% possuíam tatuagem, 7,23\% usavam piercing. 1,09\% afirmou já ter usado drogas injetáveis e 12,39\% relatou internação hospitalar. As razões de prevalência demonstraram que a utilização da tatuagem era mais comum entre os jovens, o uso de piercing mais comum entre as mulheres e o consumo de drogas maior entre o sexo masculino. Conclusões - Em suma, o reconhecimento dos fatores de risco para hepatite C permitem a correta triagem dos possíveis portadores do vírus da hepatite $\mathrm{C}$, possibilitando assim, diminuição na disseminação do vírus. Porém, só sendo possível se os serviços de saúde estejam preparados para lidar com o vírus da hepatite $C$, através da educação e conscientização da população.

DESCRITORES - Hepatite C. Fatores de risco. Grupos populacionais. Brasil, região sul. 


\section{REFERENCES}

1. Alter MJ. Epidemiology of hepatitis C virus infection. World J Gastroenterol. 2007;13:2436-41.

2. Associação Nacional de Empresas de Pesquisa. Critério de classificação econômica Brasil. São Paulo; 2008. Available from: http://www.abep.org/novo/Content. aspx?ContentID=139

3. Australian Bureau of Statistics. Deaths, Australia 1994. ABS Catalogue No. 3302.0. Canberra: AGPS; 1995.

4. Bohn MJ, Babor TF, Kranzler HR. The alcohol use disorders identification test (AUDIT): validation of a screening instrument for use in medical settings. J Stud Alcohol. 1995;56:423-32.

5. Braithwaite R, Robillard A, Woodring T, Stephens T, Arriola KJ. Tattooing and body piercing among adolescent detainees: relationship to alcohol and other drug use. J Subst Abuse. 2001;13:5-16.

6. Brandao AB, Fuchs SC. Risk factors for hepatitis $\mathrm{C}$ virus infection among blood donors in southern Brazil: a case-control study. BMC Gastroenterol. 2002;2:18.

7. Conry-Cantilena C, VanRaden M, Gibble J, Melpolder J, Shakil AO, Viladomiu L, Cheung L, DiBisceglie A, Hoofnagle J, Shih JW, et al. Routes of infection, viremia, and liver disease in blood donors found to have hepatitis $\mathrm{C}$ virus infection. N Engl J Med. 1996;334:1691-6.

8. EASL International Consensus Conference on Hepatitis C. Paris, 26-28, February 1999, Consensus Statement. European Association for the Study of the Liver. J Hepatol. 1999;30:956-61.

9. Ferrao SBR, Figueiredo JF, Yoshida CFT, Passos ADC. Prevalência elevada de hepatite $\mathrm{C}$ no distrito de Botafogo, cidade de Bebedouro, interior do Estado de São Paulo, Brasil, 2007. Cad Saúde Pública. 2009;25:460-4.

10. Ferreira, CT, Silveira TR. Hepatites virais: aspectos da epidemiologia e da prevenção. Rev Bras Epidemiol. 2004;7:473-87.

11. Gheorghe L, Csiki IE, Iacob S, Gheorghe C, Smira G, Regep L. The prevalence and risk factors of hepatitis $\mathrm{C}$ virus infection in adult population in Romania: a nationwide survey 2006-2008. J Gastrointestin Liver Dis. 2010;19:373-9.

12. Global surveillance and control of hepatitis C. Report of a WHO Consultation organized in collaboration with the Viral Hepatitis Prevention Board, Antwerp, Belgium. J Viral Hepat. 1999;6:35-47.

13. Harris DR, Gonin R, Alter HJ, Wright EC, Buskell ZJ, Hollinger FB, Seeff LB; National Heart, Lung, and Blood Institute Study Group. The relationship of acute transfusion-associated hepatitis to the development of cirrhosis in the presence of alcohol abuse. Ann Intern Med. 2001;134:120-4.

14. Hauri AM, Armstrong GL, Hutin YJ. The global burden of disease attributable to contaminated injections given in health care settings. Int J STD AIDS. 2004;15:7-16.

15. Hernández MT, Sanchez MA, Ayala L, Magis-Rodríguez C, Ruiz JD, Samuel MC, Aoki BK, Garza AH, Lemp GF. Methamphetamine and cocaine use among Mexican migrants in California: the California-Mexico Epidemiological Surveillance Pilot. AIDS Educ Prev. 2009;21(5 Suppl):34-44.
16. Instituto Brasileiro de Geografia e Estatística - IBGE. População residente-Censo Demográfico 2000. Rio de Janeiro. 2000. [2010 Jun 20]. Available in: http://www. ibge.gov.br/home/estatistica/populacao/censo2000/populacao/censo2000_populacao.pdf

17. Laumann, AE, Derick AJ. Tattoos and body piercings in the United States: a national data set. J Am Acad Dermatol. 2006;55:413-21.

18. Mahfoud Y, Talih F, Streem D, Budur K. Sleep disorders in substance abusers: how common are they? Psychiatry (Edgmont). 2009;6:38-42.

19. Mansell CJ, Locarnini SA. Epidemiology of hepatitis C in the East. Semin Liver Dis. $1995 ; 15: 15-32$.

20. Martins T, Narciso-Schiavon JL, Schiavon Lde L. [Epidemiology of hepatitis C virus infection]. Rev Assoc Med Bras. 2011;57(1):107-12.

21. Mayers LB, Chiffriller SH. Body art (body piercing and tattooing) among undergraduate university students: then and now. J Adolesc Health 2008;42:201-3.

22. Murphy EL, Bryzman SM, Glynn SA, Ameti DI, Thomson RA, Williams AE, Nass CC, Ownby HE, Schreiber GB, Kong F, Neal KR, Nemo GJ. Risk factors for hepatitis $\mathrm{C}$ virus infection in United States blood donors. NHLBI Retrovirus Epidemiology Donor Study (REDS). Hepatology. 2000;31:756-62.

23. National Institutes of Health. National Institutes of Health Consensus Development Conference Statement: Management of hepatitis C: 2002--June 10-12, 2002. Hepatology. 2002;36(5 Suppl 1):S3-20

24. Neaigus A, Friedman SR, Jose B, Goldstein MF, Curtis R, Ildefonso G, Des Jarlais DC. High-risk personal networks and syringe sharing as risk factors for HIV infection among new drug injectors. J Acquir Immune Defic Syndr Hum Retrovirol. 1996;11:499-509.

25. Nishiguchi S, Kuroki T, Fukuda K, Nakajima S, Shiomi S, Murata R, Isshiki G, Kobayashi K. Familial clustering of HCV. Lancet. 1992;339:1486.

26. Recommendations for prevention and control of hepatitis $\mathrm{C}$ virus $(\mathrm{HCV})$ infection and HCV-related chronic disease. Centers for Disease Control and Prevention. MMWR Recomm Rep. 1998;47:1-39.

27. SBH. Relatório do Grupo de Estudo da Sociedade Brasileira de Hepatologia. Epidemiologia da infecção pelo vírus da hepatite C no Brasil. GED Gastroenterol Endosc Dig. 1999;18:53-8.

28. Selm SB. Prevalence of hepatitis C virus infection among hemodialysis patients in a single center in Yemen. Saudi J Kidney Dis Transpl. 2010;21:1165-8.

29. Shepard CW, Finelli L, Alter MJ. Global epidemiology of hepatitis C virus infection. Lancet Infect Dis. 2005;5:558-67.

30. Sherriff LC, Mayon-White RT. A survey of hepatitis C prevalence amongst the homeless community of Oxford. J Public Health Med. 2003;25:358-61.

31. Strauss E. [Hepatitis C]. Rev Soc Bras Med Trop. 2001;34:69-82.

32. Wasley A, Alter MJ. Epidemiology of hepatitis C: geographic differences and temporal trends. Semin Liver Dis. 2000;20:1-16.

Received 7/10/2012 Accepted 7/2/2013 